МЕТОДИЧНІ РЕКОМЕНДАЦІЇ ПРЕДСТАВНИКАМ НАУКОВОПЕДАГОГІЧНОГО СКЛАДУ ВВНЗ ЩОДО ФОРМУВАННЯ ЗДАТНОСТІ
ДО ПРОФЕСІЙНОЇ ВЗАЄМОДІЇ В КУРСАНТІВ-ПРИКОРДОННИКІВ

\title{
METHODICAL RECOMMENDATIONS TO THE REPRESENTATIVES OF THE SCIENTIFIC AND PEDAGOGICAL COMPOSITION OF THE HIGHER EDUCATION INSTITUTIONS FOR THE FORMATION OF THE ABILITY TO PROFESSIONAL INTERACTION IN THE CURRENTS-BORDERS
}

УдК 378:141:371.134(043.3):355 DOI https://doi.org/10.32843/2663-60852019-19-2-22

\section{Тушко К.Ю.,}

канд. пед. наук, доцент, доцент кафедри педагогіки та соціально-економічних дисциплін Національної академії Державної прикордонної служби України імені Богдана Хмельницького у статті розкрито зміст методичних рекомендацій щодо фрормування здатності майбутніх ооріцерів-прикордонників до професійної взаємодії. У вступі проаналізовано значення сформованості здатності до взаємодії в майбутніх офріцерів прикордонноі служби.

Змістом методичних рекомендацій є сприйняття професійної взаємодії як невід'ємного та багатогранного компонента профе сійної підготовки майбутніх офріцерів-прикордонників, врахування положень основних методологічних підходів на засадах взаємозалежності та взаємодії, забезпечення інноваційного педагогічного середовища, забезпечення високого рівня здатності до професійної взаємодії на основі змісту навчальних дисциплін, проведення методичних семінарів для викладачів за тематичним спрямуванням щодо здатності до профресійної взаємодії, забезпечення підго товки майбутніх офріцерів-прикордонників поетапно, зәідно із спроектованою системою, здійснення постійної діагностики до та після впровадження створеної системи підготовки майбутніх прикордонників до профресійної взаємодії, часткове запровадження нелінійних організаційних форм навчання, зокрема створення модульних навчальних планів із відповідних навчальних дисциплін із метою забезпечення диференціаціїта індивідуалізації навчання, форммвання в майбутніх офріцерів-прикордонників суб'єктного досвіду профресійної взаємодії, що означає необмеження підготовки лише засвоєнням правил, вимог та стандартів їх профресійної взаємодії, забезпечення конструктивно-міжособистісних відносин в освітньому процесі між викладачами та курсантами-прикордонниками, що передбачає зміну статусно-рольових позичій і викладачів і курсантів тощо. Ключові слова: взаємодія, професійна взаємодія, майбутні офріцери-прикордонники, професійна підготовка, система підготовки, прикордонна служба, методичні рекомендації.
The author of the article tries to reveal the content of the methodological recommendations for forming the ability of future border guards to engage in professional interaction. The introduction analyses the importance of developing the ability to interact with future border guards.

The main methodological recommendations are as follows: the perception of professional engagement as an integral and multifaceted component of the professional training of future border guards; taking into account the provisions of the main methodological approaches on the basis of interdependence and interaction; providing innovative pedagogical environment; ensuring a high level of professional engagement capacity based on the content of the disciplines; conducting methodological seminars for teachers on thematic orientation on the ability to professional interaction; provide for the training of future border guards in stages, in accordance with the designed system; to carry out continuous diagnostics before and after implementation of the established system of preparation of future border guards for professional interaction; partial introduction of non-linear organizational forms of training, in particular the creation of modular curricula for relevant disciplines to ensure differentiation and individualization of learning; formation of subjective experience of professional interaction among future border guards, which means that training is not limited to mastering the rules, requirements and standards of their professional interaction; providing constructive and interpersonal relations in the educational process between teachers and border students, which implies change of status-role positions and teachers and cadets, both parties can act as a source of information, author of projects, trainer, etc.; use of the latest pedagogical technologies and more.

Key words: interaction, professional interaction, future border guards, professional training, system of training, border service, methodological recommendations.
Постановка проблеми у загальному вигляді. Пріоритетним завданням Державної прикордонної служби України є організація та здійснення охорони кордону. Це завдання вирішують військовослужбовці-прикордонники як основні представники згаданого правоохоронного відомства українського суспільства. Тому за якість виконаних задач, ефективність та високі показники щодо фрункціонування прикордонних підрозділів відповідають, насамперед, її офіцерські кадри.

Запропоноване дослідження присвячене проблемі підготовки майбутніх офріцерів-прикордонни- ків до здійснення профресійної взаємодії. Це означає, що увага буде зосереджена на змісті професійної підготовки майбутніх фахівців, яка нині потребує суттєвого оновлення і врахування актуальності проблеми їх здатності до професійної взаємодії.

Аналіз останніх досліджень і публікацій. Теоретичний аналіз проблеми формування здатності фахівців до професійної взаємодії дав змогу визначити чималу кількість наукових джерел, що розкривають її значущість та багатогранність.

Період античної епохи представлений основами механічної парадигми процесу взаємодії, яка 
стала основою для сучасних наукових праць, створених у різних галузях і великою кількістю вчених: Б. Ананьєвим [1], В. Бехтерєвим [2], Л. Виготським [4], Н. Волковою [3], Г. Гегелем [5], І. Зимньою [6], І. Кантом [7], О. Коротаєвою [8] та ін.

Виділення не вирішених раніше частин загальної проблеми. Враховуючи існування широкого спектру відповідних досліджень, варто наголосити на тому, що нами не знайдено інсрормації щодо перспективних можливостей освітнього процесу закладів вищої освіти в забезпеченні процесу фрормування здатності фрахівців до профресійної взаємодії.

Мета статті - визначення методичних рекомендацій представникам науково-педагогічного складу вищих військових навчальних закладів щодо фрормування здатності майбутніх офріцерівприкордонників до професійної взаємодії.

Виклад основного матеріалу. Протягом певного проміжку часу нами було реалізовано дослідження проблеми підготовки майбутніх офріцерів-прикордонників до професійної взаємодії. Уся робота здійснена на базі вищого військового закладу освіти - Національної академії Державної прикордонної служби України (далі - НАДПСУ). Це єдиний заклад, що забезпечує підготовку офріцерських кадрів для прикордонних підрозділів. За роки існування в ньому побудовано потужну методичну базу, яка уможливлює проведення наукових досліджень, подібних до нашого.

Представники науково-педагогічного складу намагаються забезпечувати модернізацію змісту професійної підготовки і курсантів-прикордонників і ооріцерів-магістрантів. Тому можна впевнено констатувати, що освітній процес у НАДПСУ має значні педагогічні резерви щодо вдосконалення профресійної підготовки за рівнем бакалавра. У зв'язку із тими напрацюваннями, що створені нами у вивченні проблеми підготовки майбутніх офріцерів-прикордонників до профресійної взаємодії (система підготовки, концепція, педагогічні умови), ми пропонуємо комплекс відповідних методичних рекомендацій. Ці рекомендації будуть у нагоді як представникам науково-педагогічного складу, так і командирам підрозділів, офріцерам по роботі з персоналом тощо.

Розглянемо зміст цих методичнихрекомендацій:

- сприйняттяпрофесійної взаємодії якневід'ємного та багатогранного компонента профресійної підготовки майбутніх офріцерів-прикордонників;

- врахування положень діяльнісного, акмеологічного, синергетичного, аксіологічного, системного, особистісно-орієнтовного підходів на засадах взаємозалежності та взаємодії;

- забезпечення інноваційного педагогічного середовища;

- забезпечення високого рівня здатності до професійної взаємодії на основі змісту таких навчальних дисциплін, як «Соціологія», «Етика професійної діяльності прикордонника», «Педагогіка», «Психологія», «Політичні та економічні системи» тощо;

- проведення методичних семінарів для викладачів за тематичним спрямуванням щодо здатності до профресійної взаємодії;

- забезпечення підготовки майбутніх офріцерівприкордонників поетапно, згідно із спроектованою системою;

- здійснення постійної діагностики до та після впровадження створеної системи підготовки майбутніх прикордонників до професійної взаємодії;

- часткове запровадження нелінійних організаційних фрорм навчання, зокрема створення модульних навчальних планів із відповідних навчальних дисциплін із метою забезпечення диференціації та індивідуалізації навчання;

- орормування в майбутніх офріцерів-прикордонників суб'єктного досвіду професійної взаємодії, що означає необмеження підготовки лише засвоєнням правил, вимог та стандартів їх професійної взаємодії;

- забезпечення конструктивно-міжособистісних відносин в освітньому процесі між викладачами та курсантами-прикордонниками, що передбачає зміну статусно-рольових позицій і викладачів і курсантів, обидві сторони можуть виступати джерелом інорормації, автором проектів, тренером тощо;

- використання новітніх педагогічних технологій;

- сприйняття викладачами своєї педагогічної «місії» як суб'єктивного варіанту передачі інорормації курсантам-прикордонникам;

- проектування змісту практичних завдань для майбутніх ооріцерів-прикордонників здійснювати за принципом професійного спрямування та можливостей навчальної дисципліни, а також за різними рівнями складності;

- реалізація основних та супутніх спецкурсів щодо формування здатності до професійної взаємодії;

- використання відповідної системи оцінювання під час проведення основних та супутніх спецкурсів;

- акцентування на практикорієнтованості змісту навчальних дисциплін;

- підвищення профресійної компетентності майбутніх офріцерів-прикордонників;

- запровадження передового зарубіжного досвіду щодо підготовки до профресійної взаємодії.

Запропоновані вище методичні рекомендації не $є$ остаточними, проте $є$ результатом здійсненої нами науково-пошукової діяльності. За своєю природою, гуманітарне знання не може бути остаточним, оскільки воно відображає інформацію про суспільство, а воно, своєю чергою, постійно розвивається, а отже, змінюється [8; 9]. 
Важливим узагальненням, на нашу думку, є міркування щодо важливості сфрормованості здатності майбутніх офріцерів-прикордонників до профресійної взаємодії. Першочергово необхідно усвідомити, що суспільство є системою взаємопов'язаних та взаємозалежних елементів, які постійно функціонують між собою. Ці процеси дають змогу саморегулювати соціум, самозабезпечувати його, втілювати в життя ту чи іншу систему цінностей, але найважливіше - інтегрувати його. Якщо у фрункціонуванні прикордонного відомства не враховувати ось цей аспект взаємодії, то процеси транссрормацій, переходу від відкритого та закритого типу соціального інституту будуть неможливими [11].

Сучасному суспільству притаманні неієрархічні комунікації між соціальними спільнотами (національними, політичними, релігійними тощо), а це сприяє взаємодії за принципом «усі з усіма». Таким чином, взаємодія, а зокрема професійна взаємодія, є надзвичайно важливим процесом сучасного суспільства [11].

Цінність взаємодії, профресійної взаємодії полягає у прискоренні процесів побудови соціальних організацій, структур та інституцій, які становлять фундамент громадянського суспільства [12].

Висновки. Отже, сутність педагогічних резервів освітнього процесу вищого військового навчального закладу щодо фрормування здатності до профресійної взаємодії в майбутніх офріцерівприкордонників полягає у важливості впливу на всі елементи спроектованої авторської системи. Ця система сприяє підвищенню рівня сорормованості здатності професійної взаємодії, забезпечити взаємне фрункціонування у військовому колективі, з іноземними громадянами, з мешканцями прикордоння тощо.

Перспективними напрямами подальших наукових досліджень може бути розробка відповідної методики фрормування здатності до профресійної взаємодії рахівціввійськовихформувань, анелише правоохоронних, створення дидактико-технологічного супроводу для відповідних навчальних дисциплін у військових вищих навчальних закладах.

\section{БІБЛІОГРАФІЧНИЙ СПИСОК:}

1. Ананьев Б.Г. Экспериментальная и прикладная психология : сборник ст. Ленинград. гос. ун-т. Ленинград, Изд-тво ЛгУ, 1971, 158 с.

2. Бехтерев В.М. Объективная психология. Переиздано. Москва : Наука, 1991 г. 480 с.

3. Волкова Н.П. Педагогіка : Посібник для студентів вищих навчальних закладів. Київ : Видавничий центр «Академія», 2003. 576 с.

4. Выготский Л.С. О психологических системах. Собрание соч.: В 6 т. Т. 1. Москва : Педагогика, 1982. С. 109-131.

5. Гегель Г.Ф. Феноменология духа. СанктПетербург : Наука, 1992. 444 с.

6. Зимняя И.А. Педагогическая психология. Ростовна-Дону, 1997. 125 с.

7. Кант І. Критика практичного розуму. Київ : Юніверс, 2004. $240 \mathrm{c}$.

8. Коротаєва О. Хочу, могу, умею! Обучение, погруженное в общение / Институт психологии РАН. Москва : КСП, 1997. 224 c.

9. Кожушко С.П. Навчання професійної взаємодії студентів-психологів з використанням проектної технології. Науковий вісник Донбасу. 2012. № 4. URL: Режим доступу: http://nbuv.gov.ua/UJRN/nvd_2012_4_30 (дата звернення: 12.10 .2019 р.)

10. Осипенко Л.О. Комунікативний процес як цілісна соціокультурна система: соціально-фрілософський аналіз. Гуманітарний вісник Запорізької державної інженерної академії : збірник наук. праць. Запоріжжя : Вид-во ЗДІА, 2013. № 54. С. 241-250.

11. Сорокин П.А. Преступление и кара, подвиг и награда. Санкт-Петербург, 1999. 448 с.

12. Парсонс Т. О социальных системах / Под ред. В.Ф. Чесноковой и С.А. Белановского. Москва : Академический Проект, 2002. 832 с. 